\title{
BCL-2 Family Protein
}

National Cancer Institute

\section{Source}

National Cancer Institute. BCL-2 Family Protein. NCI Thesaurus. Code C153109.

A family of proteins that all contain at least one of four $\mathrm{Bcl}-2$ homology domains $(\mathrm{BH})$.

These proteins are involved in the regulation of apoptosis. 